\title{
A comparative study on phonological acquisition and performance in phonological awareness by children exposed to a bilingual or monolingual family environment
}

Ana Rita Brancalioni(1)

Ana Paula Bogoni( ${ }^{(1)}$

Diane Pinto da Silva(1)

Vanessa Giacchini(2)

1) Universidade de Passo Fundo, Passo Fundo, Rio Grande do Sul, Brasil.

(2) Universidade Federal do Rio Grande do Norte, Natal, Rio Grande do Norte, Brasil.

This research was carried out at the University of Passo Fundo, Speech-

Language Pathology and Audiology

Course, Passo Fundo, Rio Grande do Sul, Brazil.

Research support source: This study was financed, in part, by the Coordenação de Aperfeiçoamento de Pessoal de Nível Superior (CAPES), Brazil - Finance Code 001.

Conflict of interests: Nonexistent

\section{(c) (i)}

Received on: February 2, 2018 Accepted on: September 28, 2018

Corresponding address: Vanessa Giacchini

Av. Júlio Borella, 1547/202

CEP: 99150-000 - Marau, Rio Grande do Sul, Brasil

E-mail: fga.vanessa@hotmail.com

\section{ABSTRACT}

Objective: to verify and compare phonological acquisition and performance in phonological awareness tasks among children exposed to a bilingual (Brazilian Portuguese and German) or monolingual family environments (Brazilian Portuguese).

Methods: a sample of 32 children of both sexes aged 5 years were divided into the bilingual group (13 children), who lived daily with people who spoke German and Portuguese, and the monolingual group (19 children), who lived daily with people who spoke only the Portuguese language. Phonological acquisition and phonological awareness skills were assessed using protocols standardized for Brazilian Portuguese and statistically analyzed using the Fisher exact test and Mann-Whitney test, considering $\mathrm{p}<0.05$.

Results: the results revealed that a greater number of subjects demonstrated atypical phonological acquisition in the bilingual group and scored worse results in the phonological awareness skills evaluation. Phonological processes were similar in both groups. None of the results obtained were statistically significant.

Conclusion: deviant phonological acquisition was superior in the bilingual family environment group. Phonological processes were similar for both groups. In the phonological awareness tasks, children in the bilingual family environment group obtained better results only for the phonemic synthesis tasks. For other tasks, children in the monolingual family group achieved better results.

Keywords: Multilingualism; Child; Child Development; Speech; Language 


\section{INTRODUCTION}

Language is the main mean of communication between children and the world in which they live. Through interaction with others, they develop and refine their communication and interaction skills ${ }^{1}$. Language is considered the first form of the socialization of children, and it is initially developed from communication with their relatives through verbal instructions, conversations, and stories.

The input is highly important in the construction of the phonological system of sounds of the mother tongue. A study ${ }^{2}$ evaluating the characteristics of phonological acquisition from a multi-representational analysis verified that linguistic aspects change depending on the linguistic exposure of the child. In some cases, differences in development were observed because of the input children were exposed to.

An analysis guided by the theory of language acquisition $^{3}$ revealed that children are born with an innate ability to acquire language, the Universal Grammar, as they acquire it from imperfect information. Children justify the existence of a Universal Grammar, because even when exposed to a precarious linguistic system, they are able to master their natural language in a relatively short period, even though the input comprises incomplete sentences and a limited system of constructions.

The author of the theory ${ }^{3}$ presents linguistic universals, which indicate the "principles and parameters" before which each language is set as a determined selection within the combination of available possibilities. To the linguist, grammar is formed by common principles used in all languages and by parameters defined by the language to which one is exposed. This causes changes between languages and within the same language. Based on universal and innate parameters, the role of children is to analyze the input received and then process it to assign the value of each parameter.

When children are exposed to a bilingual environment in the period of language acquisition and to languages with different syntactic structures, could this affect phonological acquisition and analysis of the parameters of their mother tongue? Some factors may interfere in children's cognitive development and language acquisition, namely biological or cognitive factors resulting from affective and environmental issues or linguistic input.

Children assimilate the language of the speakers with whom they live and of the cultural environment in which they are inserted ${ }^{4}$. As a result, a richer linguistic input environment enables the better development of important skills for phonemic discrimination. One study suggests that bilingual children are capable of developing more sophisticated perceptual skills to distinguish the different languages to which they are exposed 5 .

According to numerous studies ${ }^{6-10}$, bilingual children perform better in phonological awareness skills, are more precise in naming verbs and nouns, have better cognitive ability, and perform better in tasks requiring creativity and logical reasoning.

Children living in bilingual situations may develop difficulties with speech or language and communication in general, like any other child, without this being directly related to exposure to or use of two languages simultaneously ${ }^{11}$. The development of children's language skills reflects the quality and quantity of their linguistic experiences ${ }^{11}$.

In general, it has been observed that the phonological system is typically similarly constructed among monolingual children. Studies ${ }^{12,13}$ affirm that the typical acquisition of the Brazilian Portuguese phonological system occurs from birth until approximately the age of five years in a gradual, non-linear manner, respecting the differences of each speaker. However, individual variations are possible in the segmental and prosodic domain. During the process of language acquisition, the child faces a conflict between the target phonological system (of the adult) and its production, encountering limitations in the capacity of categorization, articulation, motor planning, phonological memory, and auditory processing ${ }^{13,14}$.

Simplifications in speech, called phonological processes, must happen at specific ages during language acquisition. However, when these processes become persistent at ages when they are no longer expected in the phonological acquisition process, without the presence of known and detectable etiological factors such as intellectual deficit, neuromotor disorders, or alterations in the structure of phono-articulatory organs, a phonological disorder is present $^{13,15}$.

A phonological disorder is a change in speech that can be understood as the inadequate use of language phonemes, characterized by omissions and substitutions that cause difficulties in speech intelligibility ${ }^{16}$. A phonological disorder occurs in the absence of organic factors that justify the child's speech difficulty, 
and is considered an inability to correctly employ the contractive traits of the language ${ }^{17,18}$.

Studies have evaluated phonological disorder and performance in phonological awareness tasks ${ }^{19-21}$. Phonological awareness is defined as the ability to identify, isolate, manipulate, combine, and mentally and deliberately segment the phonological segments of the language. Phonological awareness is developed in early childhood, and is progressive, improving over time and with literacy. The development of phonological awareness depends on linguistic experiences, the cognitive ability of the child, specific characteristics of different skills, and formal exposition of the alphabetic system during reading and writing acquisition ${ }^{20-23}$.

Phonemic awareness is the most complex level of phonological awareness and the last capacity to be developed. It is related to understanding how phonemes work within the word ${ }^{24}$. The phoneme is the smallest unit of analysis in the word, and most words consist of a set of phonemes. According to the literature, at five years of age, children are expected to have metaphonological abilities, as long as the tasks are adapted to their linguistic and cognitive reality, with more difficult tasks related to phonemic awareness, as there is still no writing support ${ }^{20,25}$.

According to one study ${ }^{6}$, with learning to read comes additional knowledge about linguistic structure. In this way, phonological awareness becomes more complex, and consequently, formal instructions explaining the rules of correspondence of speech sounds in alphabetic writing (phoneme/grapheme relations) are necessary to ensure that phonemic awareness develops afterwards ${ }^{20,24}$.

Bilingual children are known to have better metacognitive skills than monolingual children, besides presenting more expressive results in perception tests $^{25,26}$. However, the following question arises: When children are not bilingual but live in an environment in which two languages are used simultaneously, is there a change in the process of acquiring the phonology of their language? Are their metacognitive skills better, worse, or similar to the skills of children living in monolingual environments?

The objective of this work is to verify and compare phonological acquisition and performance in phonological awareness tasks among children exposed to a bilingual (Brazilian Portuguese and German) or monolingual family environment (Brazilian Portuguese). It is important to verify if a bilingual family environment contributes to possible delays in the acquisition of phonology for an increased use of phonological processes or worse performance in phonological awareness tasks.

\section{METHODS}

\section{Ethical Considerations and Characteristics of the Study}

This study is a cross-sectional quantitative observational study. It was developed in schools in the city of Chapada, a city colonized by Germans at the beginning of the last century. This small city is located in the Alto Uruguai region, North West of the state of Rio Grande do Sul, Brazil. Its population is approximately 9,377 inhabitants, of which 5,573 reside in urban areas and 3,804 in rural areas.

The study was approved by the Research Ethics Committee of the University of Passo Fundo, under number 23282713.5.0000.5342, of the National Commission of Ethics and Research (CONEP). It follows all the required norms for conducting scientific research according to resolution CNS 466/12 and its complements.

Prior to the participation of children in the research, their parents and/or guardians signed the Informed Consent Form (ICF) authorizing their participation therein. In addition, the school principals signed the Institutional Authorization Form that allowed the collection of data in the institution.

\section{Characteristics of the sample}

To develop the research, all schools in the city were contacted (one state and four municipal). The objectives of the work and importance in the educational context were explained to them. After institutional authorization, all children aged five years were invited to participate $(5: 0$ to $5: 11,29)$. Those responsible for the children who accepted the invitation signed the ICF and answered an objective questionnaire. The questions dealt with the development of speech and language, the child's linguistic environment, signs of delay in language acquisition, and reports of developmental stuttering. There were also questions regarding the proficiency and use of the German language in the child's family environment.

In total, 60 children were invited to participate in the research. However, only 32 met the inclusion criteria, which were as follows: the signed ICF; return of the questionnaire answered by those responsible; and the child was aged between 5:0 and 5:11,29 years, had 
no language delays, and demonstrated no indicative signs of neurological disorders such as syndromes, emotional or cognitive alterations, or attention deficit hyperactivity disorder.

Ultimately, the sample consisted of 32 children, of whom 19 were male and 13 female. They were divided into two groups: the monolingual group (MG) and bilingual group (BG). The MG was composed of 19 Brazilian Portuguese-speaking children who lived daily in their home environment with only Brazilian Portuguese speakers. The BG was composed of 13 children, who were also speakers of Brazilian Portuguese, but who lived daily in a family environment with at least one person (father, mother, brother, and/ or grandparents) who fluently spoke German with the child.

\section{Evaluations and collected data}

All children underwent three stages for the purposes of this study, namely screening, phonological evaluation, and phonological awareness evaluation. The screening was performed through spontaneous speech and children's storytelling (The Three Little Pigs, Little Red Riding Hood, and Pinocchio), in which the semantic, syntactic, and pragmatic components of the language were observed alongside the logical organization of thought, adequacy of responses, and execution of simple and complex orders.

The initial screening performed with parents who wanted their children to participate in the study consisted of a brief questionnaire asking about the child's development.

The second stage comprised the phonological evaluation, carried out using the ABFW-Phonology Instrument ${ }^{27}$, which entails naming and imitation tests. This evaluation was performed to obtain data for the analysis and verify the children's phonological development. In the first test, the examiner asked the child to name the figures presented. If the child did not know, the researcher named the figure, and thereafter, presented five subsequent figures including the one the child could not name. In the second test, the researcher requested that the child repeat the word heard. In both the naming and imitation tests, speech production and productive phonological processes were analyzed for both groups. Subsequently, the children with atypical phonological acquisition were identified considering the ages for the suppression of each phonological process.

The third evaluation aimed to obtain data to analyze the children's production. It was conducted using the Phonological Awareness Test by Oral Production $(\text { PAT-OP })^{28}$, which evaluates children's ability to manipulate speech sounds by orally expressing the result of this manipulation. The test has ten subtests that incorporate the evaluation of supraphonemic and phonemic components. Training preceded each task to ensure understanding. A correct answer scored a point, an incorrect answer was assigned zero, and half a point was given when the child provided a partially correct answer.

The children's performance in the PAT-OP ${ }^{28}$ is presented as a score or frequency of correct answers, with a maximum of 40 possible correct answers. The number of correct answers was compared with the normative data for children aged five years, enabling a performance evaluation of very low, low, medium, high, or very high.

\section{Data analysis}

The data collected were transcribed in the test protocols and tabulated in an electronic spreadsheet. After that, they were statistically analyzed using the Fisher exact test and Mann-Whitney test, which were conducted in the Bioestat 5.0 software with a significance level of $5 \%(p<0.05)$.

\section{RESULTS}

Figure 1 illustrates the distribution of children according to the phonological acquisition for the $B G$ and MG. Atypical phonological acquisition was higher for children exposed to a bilingual environment $(n=6)$ than those in a monolingual environment $(n=4)$. However, this difference was not statistically significant, as per the Fisher Exact test $(p=0.1325)$. 


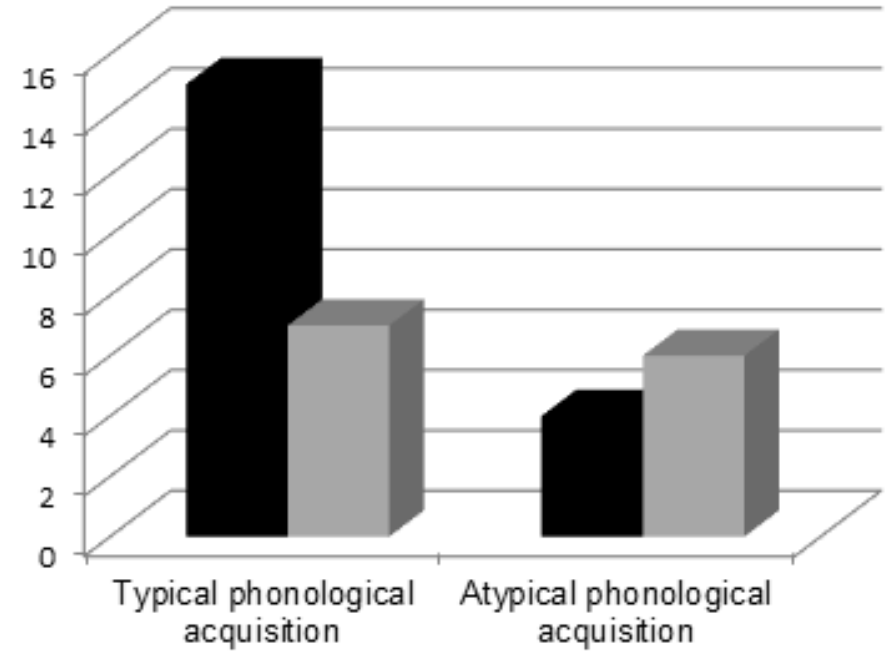

Note: Fisher's Exact Test $p=0.1325$
- Monolingual Group

— Bilingual Group

Figure 1. Distribution of children according to phonological acquisition in both groups

Table 1 shows the productive phonological processes found for the sample. For both groups, the phonological processes that occurred were consonant harmony, palatal fronting, liquid simplification, cluster simplification, stop devoicing, and final consonant simplification. No statistically significant difference was evident in the distribution and frequency of these processes.

Table 1. Analysis of the productive phonological processes of children in the bilingual and monolingual groups

\begin{tabular}{lccccc}
\hline \multirow{2}{*}{ Phonological Processes } & \multicolumn{2}{c}{ Group B - Bilingual Environment } & Group M - Monolingual Environment & \\
\cline { 2 - 4 } & Occurs n (\%) & $\begin{array}{c}\text { Does not occur } \\
\mathbf{n ~ ( \% )}\end{array}$ & Occurs n (\%) & $\begin{array}{c}\text { Does not occur } \\
\text { n (\%) }\end{array}$ & p \\
\hline Syllable Reduction & $0(0.00)$ & $13(100.00)$ & $0(0.00)$ & $19(100.00)$ & $\#$ \\
Consonant Harmony & $1(7.69)$ & $12(91.31)$ & $0(0.00)$ & $19(100.00)$ & $\#$ \\
Stopping of Fricatives & $0(0.00)$ & $13(100.00)$ & $0(0.00)$ & $19(100.00)$ & $\#$ \\
Velar Posteriorization & $0(0.00)$ & $13(100.00)$ & $0(0.00)$ & $19(100.00)$ & $\#$ \\
Palatal Posteriorization & $0(0.00)$ & $13(100.00)$ & $0(0.00)$ & $19(100.00)$ & $\#$ \\
Velar Fronting & $0(0.00)$ & $13(100.00)$ & $0(0.00)$ & $19(100.00)$ & $\#$ \\
Palatal Fronting & $2(15.38)$ & $11(84.62)$ & $2(10.52)$ & $17(89.48)$ & 0.5419 \\
Liquid Simplification & $5(38.46)$ & $8(61.34)$ & $5(26.32)$ & $14(73.68)$ & 0.5652 \\
Cluster Simplification & $8(61.34)$ & $5(38.46)$ & $8(42.11)$ & $11(57.89)$ & 0.2363 \\
Final Consonant Simplification & $1(7.69)$ & $12(91.31)$ & $2(10.52)$ & $17(89.48)$ & $\#$ \\
Stop Voicing & $0(0.00)$ & $13(100.00)$ & $0(0.00)$ & $19(100.00)$ & $\#$ \\
Fricative Voicing & $0(0.00)$ & $13(100.00)$ & $0(0.00)$ & $19(100.00)$ & $\#$ \\
Stop Devoicing & $1(7.69)$ & $12(91.31)$ & $1(5.26)$ & $18(94.74)$ & $\#$ \\
Fricative Devoicing & $0(0.00)$ & $13(100.00)$ & $0(0.00)$ & $19(100.00)$ & $\#$ \\
\hline
\end{tabular}

Caption: \#: without variation to carry out the statistical test Note: $p$ : P-Value of Fisher's Exact Test. 
Figure 2 illustrates the productive phonological processes presented. It shows that the same phonological processes, with the exception of consonant harmony, were verified for children in both the $B G$ and MG.
Figure 3 presents the box-plot diagram of the total number of correct answers provided by the children in the phonological awareness skills evaluation. The average score in the test, represented by the line inside the box, was lower for BG (13.12) than MG (13.87). This difference was not statistically significant.

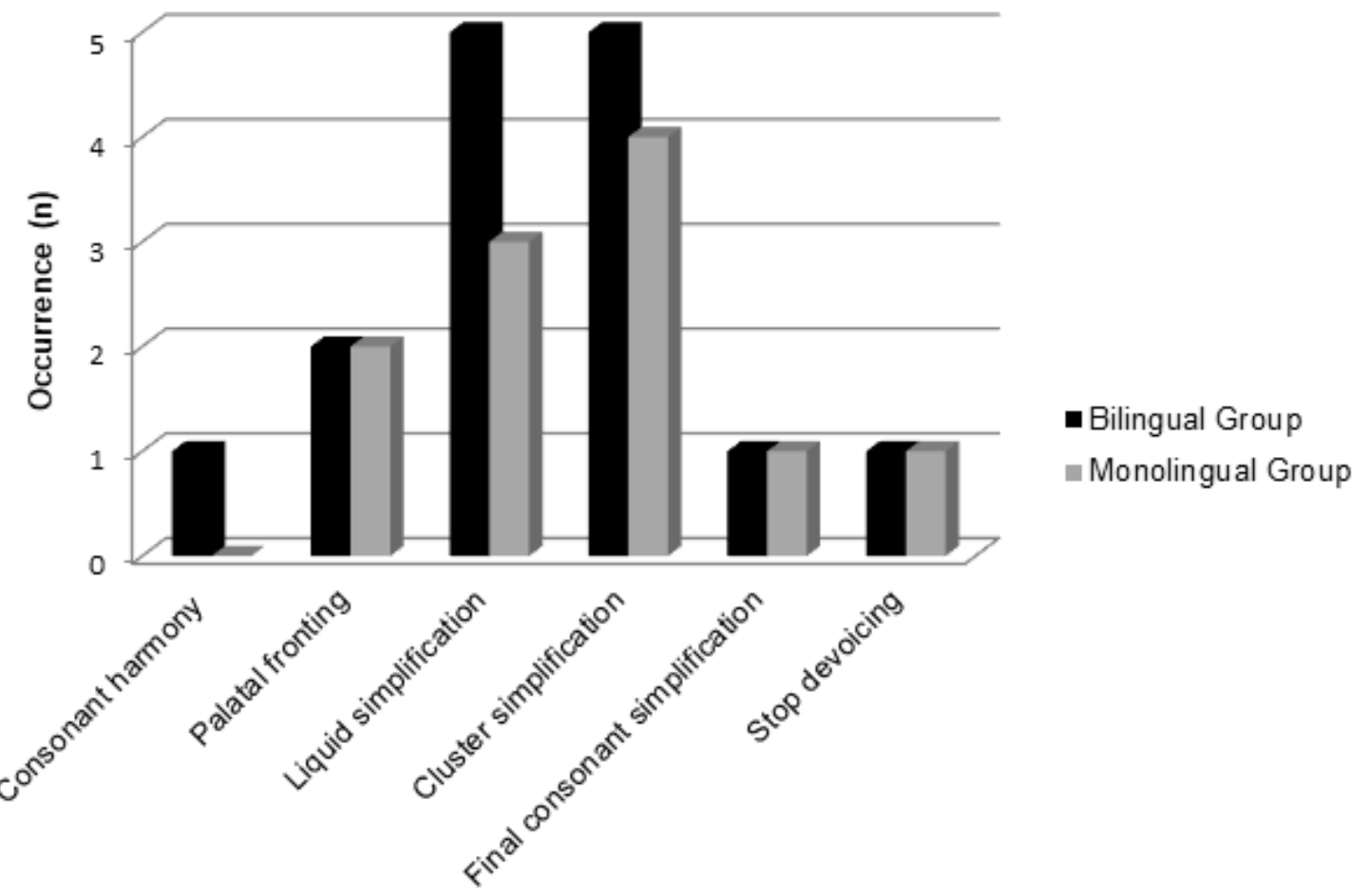

Figure 2. Productive phonological processes for children in both groups

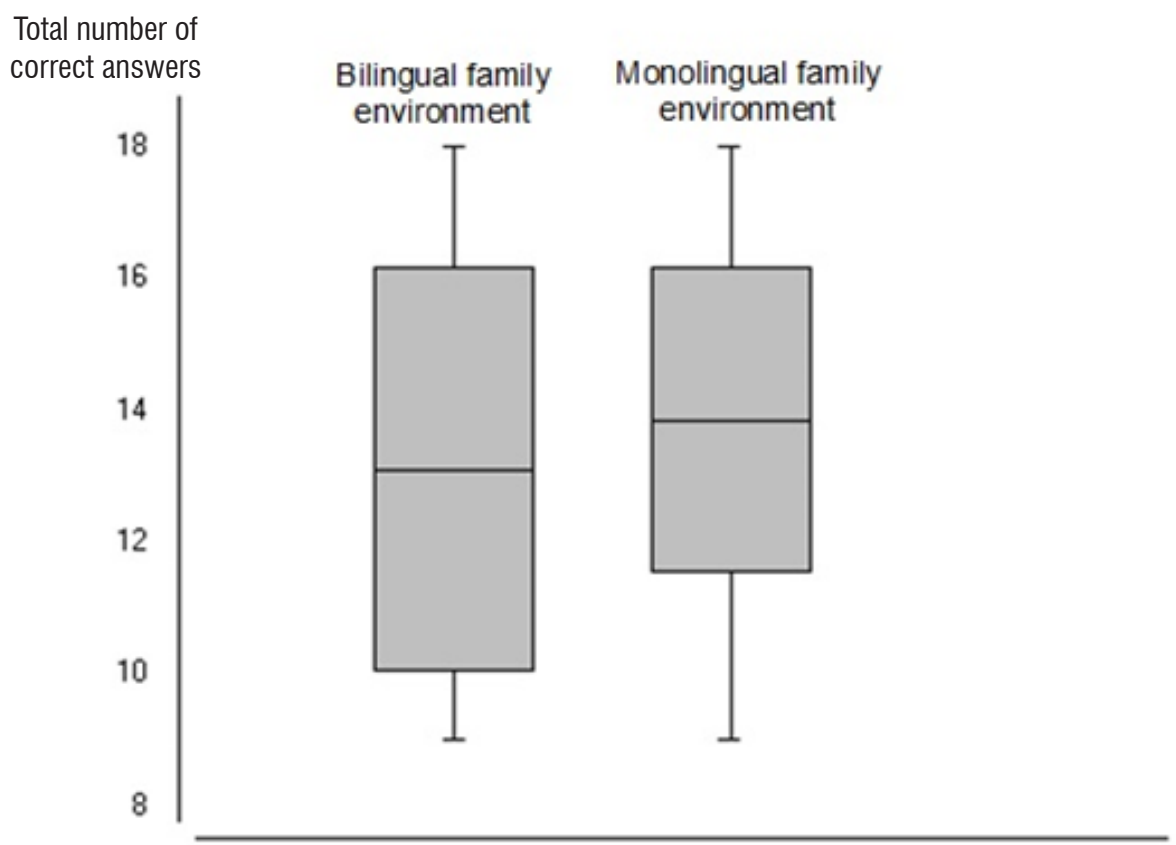

Note: Mann-Whitney test, value of p: 0.1776 .

Figure 3. Box-plot chart for the total of correct answers in the phonological awareness test by oral production for the bilingual and monolingual groups 
Table 2 presents performance in the phonological awareness tasks for children in the $B G$ and MG. It shows that all children in both groups correctly performed the task of syllable synthesis. In the phoneme synthesis task, the BG children scored a higher average than did the children in the other group. Regarding tasks of rhyme, alliteration, and syllable segmentation, the MG children achieved better results. No children in the two groups performed the tasks of phoneme segmentation, syllable manipulation, phoneme manipulation, syllable transposition, and phoneme transposition.

Table 2. Performance in the tasks of the phonological awareness test by oral production for children in the bilingual and monolingual groups

\begin{tabular}{lccc}
\hline Tasks & $\begin{array}{c}\text { BG - Bilingual Environment } \\
\text { Mean (standard deviation) }\end{array}$ & $\begin{array}{c}\text { MG - Monolingual } \\
\text { Environment } \\
\text { Mean (standard deviation) }\end{array}$ & P-Value \\
\hline Syllable Synthesis & $4.00(0.00)^{*}$ & $4.00(0.00)^{*}$ & $\#$ \\
Phoneme Synthesis & $1.19(0.99)$ & $1.02(1.03)$ & 0.3090 \\
Rhyme & $2.38(1.12)$ & $2.63(1.11)$ & 0.2330 \\
Alliteration & $2.15(1.34)$ & $2.42(0.96)$ & 0.3226 \\
Syllable segmentation & $3.38(0.77)$ & $3.79(0.35)$ & 0.0866 \\
Phoneme segmentation & $0.00(0.00)^{* *}$ & $0.00(0.00)^{* *}$ & $\#$ \\
Syllable manipulation & $0.00(0.00)^{* *}$ & $0.00(0.00)^{* *}$ & $\#$ \\
Phoneme manipulation & $0.00(0.00)^{* *}$ & $0.00(0.00)^{* *}$ & $\#$ \\
Syllable transposition & $0.00(0.00)^{\star *}$ & $0.00(0.00)^{* *}$ & $\#$ \\
Phoneme Transposition & $0.00(0.00)^{* *}$ & $0.00(0.00)^{* *}$ & $\#$ \\
\hline
\end{tabular}

Caption: *: correct answers of all items of the test; **: incorrect answers of all items of the test; \#: without variation to carry out the statistical test Note: P-Value: Significance of the Mann-Whitney Test

Figure 4 illustrates the distribution of the children's performance based on the standard score of the phonological awareness test by oral production for

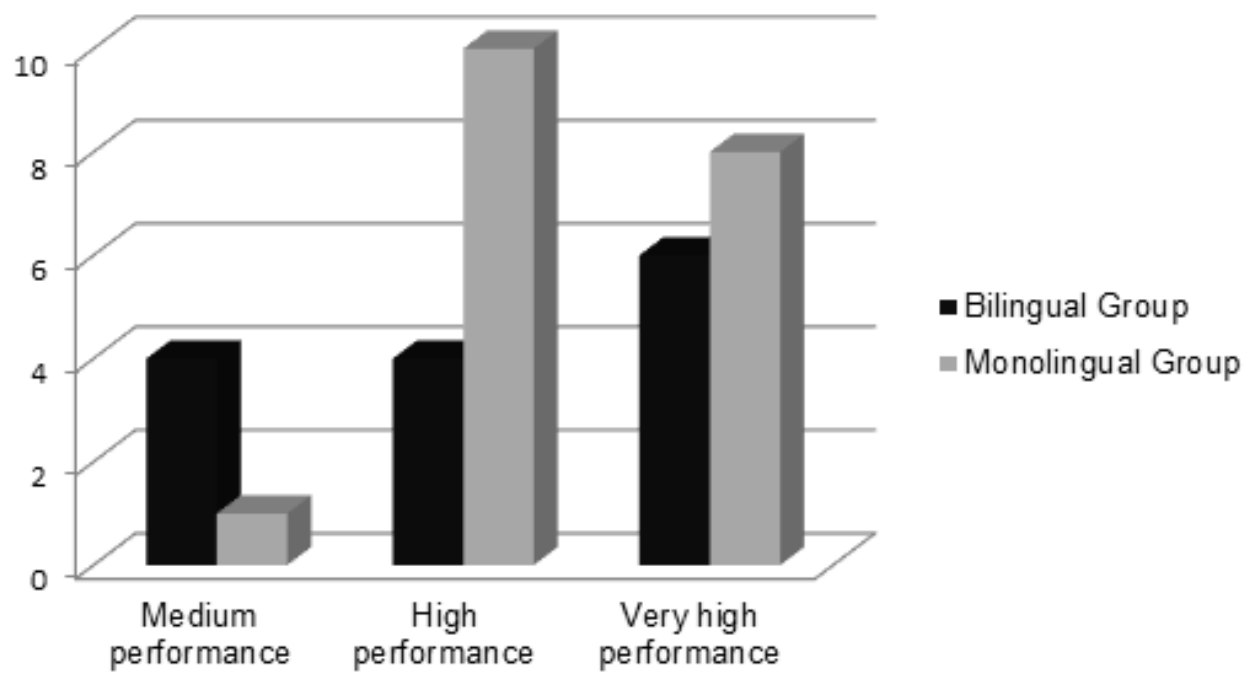

$B G$ and MG. It shows that no child had low or very low standard scores. In addition, the highest incidence was very high for $B G$ and high for $M G$.

Figure 4. Distribution of performance from the standard score in the phonological awareness test by oral production for children of the bilingual and monolingual groups according to normative data 


\section{DISCUSSION}

The numerically verified difference between the analyzed groups was not statistically significant, both in the questions involving the phonological system and those related to the development of phonological awareness skills.

The results of the present study reveal a higher incidence of atypical phonological acquisition for children exposed to a bilingual environment. This finding agrees with some studies ${ }^{10,29}$ referring to the existence of several phenomena that influence the acquisition and development of language, including exposure to two languages in the family environment.

Comparing the phonological processes of children exposed to a bilingual and monolingual family environment confirmed that they used the same processes, regardless of environment. This corroborates a study ${ }^{30}$ of children exposed to a bilingual environment that confirmed the same strategies of repair during acquisition by bilingual and monolingual children. Thus, the phonological development of children exposed to a bilingual environment may differ from that for children exposed to a monolingual environment. The differences are related to superficial aspects, but in general, the same phonological processes are used, although these are more pronounced in children exposed to a bilingual environment.

Children with atypical phonological acquisition exposed to a bilingual or monolingual environment demonstrated the same productive phonological processes. These findings suggest that exposure to a bilingual environment has no significant influence on phonological acquisition. A study ${ }^{31}$ affirms that phonological knowledge is influenced by age, metacognitive ability, level of schooling, proximity to written content, and type of task performed.

The most frequent productive phonological processes were liquid simplification and cluster simplification. This mirrors the results of studies ${ }^{12,15,18,20}$ that verified phonological processes involving the liquid class as the most frequent in the population with phonological disorder.

Although the desonorization process is frequent in German speakers, who have difficulties in distinguishing between voiceless and voiced stops (both when the phoneme-grapheme (reading) association should occur and in speech), the exposure of children to a bilingual environment (Portuguese Brazilian and German) does not influence the occurrence of this process in their speech. As such, other factors such as the presence of otitis ${ }^{32}$, difficulty in auditory discrimination $^{24}$, and severity of phonological deviation ${ }^{33,34}$ may affect the presence of the devoicing process.

Regarding the performance of phonological awareness, the data from the present study reveal that children exposed to a bilingual family environment scored fewer correct answers on average in the test $^{28}$, but no statistical difference was evident. Such data cannot be compared with the literature, since no studies were found that evaluated performance in the phonological awareness task of monolingual children exposed to a bilingual environment. However, one study $^{30}$ reported that children simultaneously exposed to two languages (English and Brazilian Portuguese) during the period of language acquisition and development demonstrated good performance in phonological awareness tasks, indicating that the simultaneous acquisition of two languages does not impair the phonological awareness of Portuguese.

Furthermore, studies ${ }^{6,7,35,36}$ that evaluated the performance of bilingual and monolingual children in phonological awareness tasks revealed the superior performance of children in the bilingual group. However, these studies contrast other research in the literature ${ }^{5,37}$ that did not confirm their superior language performance compared to monolingual speakers.

Evidence points out that the verbal abilities of bilingual children are lower than those of monolingual children $^{5}$. The vocabulary of bilingual children (analyzing only one language) is smaller than that of monolingual children of the language analyzed. In naming tasks, bilingual children may present slower and less accurate results than their monolingual peers ${ }^{20,23}$.

Another study ${ }^{38}$ highlighted that bilingual children had higher scores than monolinguals in cognitive skills tests. They also have advantages in terms of understanding the communication needs of their conversation partners. Research ${ }^{5}$ analyzing the effect of bilingualism on cognition in adulthood found that bilingualism has little or no influence, but has an important role in old age, helping in the cognitive reserve.

In this study, the sample, namely children exposed to a bilingual environment, obtained better results in phoneme synthesis tasks than did children exposed to a monolingual environment. A similar result was observed in other studies 6,7 , in which the group of bilingual children performed better than the monolingual group in a phoneme synthesis task. However, this finding contrasts that of another study ${ }^{39}$, which found that 
bilingual children demonstrated inferior performance in the task of phonemic awareness.

Considering the tasks of rhyme, alliteration, and syllable segmentation, children exposed to a monolingual environment obtained a better result. This result is similar to that in a study ${ }^{6}$ in which the group of monolingual children performed better in the syllable segmentation task. According to the authors, this is associated with the sound characteristics of Brazilian Portuguese, which is a syllabic language in which syllables are easily recognized.

The study sample did not provide answers regarding the tasks of phoneme segmentation, phoneme manipulation, and phoneme transposition. This can be explained by the fact that phonemic awareness tasks require further analysis. They have a higher degree of complexity and are directly dependent on the alphabetic code ${ }^{6,7,22}$. Another study ${ }^{40}$, based on the results of phonological awareness tests of pre-school children, revealed that the task of phoneme segmentation was easier than that of syllable segmentation.

Analyzing the results of this study in general, the bilingual environment did not significantly affect phonological acquisition and performance in phonological awareness skills. Before such findings, it was possible to infer that exposure to bilingual environments has no negative or positive impact on the development of phonology and phonological awareness skills.

According to one study ${ }^{38}$, in the early stages of second language acquisition, children may experience delayed development compared to monolingual children. However, most bilingual children do not have a lower or higher capacity than monolingual children in any of the areas of language acquisition. The observed delays are small and do not last very long. It is important to verify the interference of another language in the acquisition of the target language phonology, even when the acquisition of a new language is not analyzed.

\section{CONCLUSION}

Although there was no statistically significant difference between the groups, the prevalence of atypical phonological acquisition was numerically higher for children exposed to a bilingual family environment. The phonological processes found were similar for children exposed to the bilingual and monolingual environment.

In phonological awareness tasks, children exposed to the bilingual environment obtained better results only in the task of phoneme synthesis. In the other phonological awareness tasks, children exposed to the monolingual environment achieved better results.

However, none of the results of the present study were statistically significant. Thus, for the sample in this study, it is concluded that the bilingual family environment does not significantly interfere in phonological acquisition and performance in phonological awareness skills. Therefore, further studies on the influence of different linguistic inputs during the period of language acquisition are necessary.

\section{REFERENCES}

1. Hubner EP, Ardengui LG. Input materno e aquisição da linguagem: análise das dádes comunicativas entre mães e filhos. Bol Psicol [Internet]. 2010 [cited 2017 Jul 14];LX:029-43. Available from: http://pepsic.bvsalud.org/pdf/bolpsi/v60n132/ v60n132a04.pdf

2. Cristófaro TS, Abreu CG. Aquisição fonológica na perpectiva multirepresentacional. Rev Let Hoje [Internet]. 2007 [cited 2017 Jul 13];42(1):179-91. Available from: http://revistaseletronicas.pucrs.br/ ojs/index.php/fale/article/viewFile/679/493

3. Chomsky N. Knowledge of language: its nature, origin, and use [Internet]. Praeger; 1986 [cited 2017 Jul 14]. 307 p. Available from: https:// books.google.com.br/books? id = b0VZPtZDL8k C\&pg $=$ PR3\&hl $=$ pt-BR\&source $=$ gbs_selected pages $\&$ cad $=2 \# v=$ onepage $\& q \& f=$ false

4. Yule G. The stufy of language [Internet]. 4th ed. Cambridge; 2010 [cited 2017 Jul 13]. 340 p. Available from: http://faculty.mu.edu.sa/public/ uploads/1378843468.6083The Study Of Language (4th Edition(.pdf

5. Bialystok E, Craik F, Luk G. Bilingualism: consequences for mind and brain. Trends Cogn Sci. 2012;16(4):240-50.

6. Souza LBR, Leite AGC. Profile of phonological awareness in bilingual and monolingual children. CoDAS [Internet]. 2014 [cited 2017 Jul 14];26(1):61-7. Available from: http://www.scielo.br/ pdf/codas/v26n1/2317-1782-codas-26-01-00061. pdf

7. Lasch SS, Mota HB, Cielo CA. Consciência fonológica: o desempenho de meninos e meninas bilíngues e monolíngues. Rev. CEFAC [Internet]. 2010 [cited 2017 Jul 14];12(2):202-9. Available from: http://www.scielo.br/pdf/rcefac/v12n2/116-08. pdf 
8. Marian $\mathrm{V}$, Faroqi-Shah $\mathrm{Y}$, Kaushanskaya M, Blumenfeld HK, Sheng L. Bilingualism: consequences for language, cognition, development, and the brain. ASHA Leader. 2009.

9. Mendonça PV da CF, Fleith D de S. Relationship between monoliguals and bilinguals' creativity, inteligence, and self-concept. Psicol Esc e Educ [Internet]. 2005 [cited 2017 Jul 14];9(1):59-70. Available from: http://www.scielo.br/pdf/pee/ v9n1/9n1a06.pdf

10. Saliby CKA, dos Santos C, Hreich EK, Messarra C. Assessing lebanese bilingual children: the use of cross-linguistic lexical tasks in lebanese arabic. Clin Linguist Phon [Internet]. 2017 [cited 2017 Jul 21] 31(11-12):874-92. Available from: https://www.ncbi. nlm.nih.gov/pubmed/28441074.

11. Hoff E, Core C. Input and language development in bilingually developing children. Semin Speech Lang [Internet]. 2013 Nov [cited 2017 Jul 14];34(4):215-26. Available from: http://www.ncbi. nIm.nih.gov/pubmed/24297614

12. Silva MK da, Ferrante C, Borsel J Van, Perreira MM de B. Phonological acquisition of brazilian portuguese in children from Rio de Janeiro. J Soc Bras Fonoaudiol [Internet]. 2012 [cited 2017 Jul 17];24(3):248-54. Available from: http://www.scielo. $\mathrm{br} /$ scielo.php?script $=$ sci_arttext\&pid $=$ S217964912012000300010\&lng=en. $\quad$ http://dx.doi. org/10.1590/S2179-64912012000300010.

13. Ceron MI, Gubiani MB, de Oliveira CR, KeskeSoares M. Factors influencing consonant acquisition in brazilian portuguese-speaking children. J Speech Lang Hear Res [Internet]. 2017 Apr 14 [cited 2017 Dec 6];60(4):759. Available from: http://jslhr.pubs.asha.org/article. aspx?doi=10.1044/2016_JSLHR-S-15-0208

14. Mezzomo CL, Giacchini V, Dias RF, Luiz SW, Lopes SG. Aquisição da coda simples e complexa com /S/ em crianças com desvio fonológico. Rev. CEFAC. 2013;(2):17-24.

15. Mezzomo CL, Vargas DZ, Dias RF. Strategies used by children with typical and atypical phonological development during the blocked syllable acquisition. Rev. CEFAC [Internet]. 2015 [cited 2017 Jul 17];17(Supl1):27-34. Available from: http://revistaseletronicas.pucrs.br/ojs/index.php/ letronica/article/view/7097
16. Rosado IM, Donicht G, De Simoni SN, Pagliarin KC, Keske-Soares M. Perception of the intelligibility and severity level of speech sound disorders by speech language pathologists and non-professionals. Rev. CEFAC [Internet]. 2017 [cited 2017 Jul 17];19(2):233-41. Available from: http://www.scielo. $\mathrm{br} / \mathrm{pdf} / \mathrm{rcefac} / \mathrm{v} 19 \mathrm{n} 2 / 1982-0216-r c e f a c-19-02-00233$. pdf

17. Giacchini V, Mota HB, Lazzarotto-Volcão C. Standard model of structures and contrast acquisition - proposal for phonological evaluation in the brazilian portuguese. J Child Lang Acquis Dev. 2016;4(3):78-97.

18. Schneider GB, Dias RF, Mezzomo CL. Analysis of the distinctive features and of the phonetic and phonological systems in different severities of phonological disorder. Rev. CEFAC [Internet]. 2014 [cited 2017 Jul 17];16(6):1850-9. Available from: http://www.scielo.br/pdf/rcefac/v16n6/1982-0216rcefac-16-06-01850.pdf

19. Giacchini V, Mota HB, Mezzomo CL. The details in the therapeutic process to the consonant clusters acquisition in the speech of children with phonological disorder. Rev. CEFAC. 2012;(2):17-23.

20. Ribas LP, Bartz DW, Rodrigues G, Silva D, Vieira Peruch $\mathrm{C}$, Zencke $\mathrm{K}$ et al. Consciência fonológica em crianças com desvio fonológico. Domínios de Lingu@gem [Internet]. 2013 [cited 2017 Jul 17];7(2):1-10. Available from: http://www.seer. ufu.br/index.php/dominiosdelinguagem/article/ viewFile/23506/13587

21. Stefanini MR, Oliveira BV de, Marcelino FC, Maximino LP. Performance in phonological awareness of children with phonological disorder: comparison of two instruments. Rev. CEFAC [Internet]. 2013 [cited 2017 Jul 17] 15(5):1227-35. Available from: http://www.scielo.br/pdf/ rcefac/2013nahead/171-11.pdf

22. Bigochinski E, Eckstein MPW. A importância do trabalho com a com a consciência fonológica para a aprendizagem da leitura e da escrita. Rev Eletrônica do Curso Pedagog das Faculdades OPET [Internet]. 2016 [cited 2017 Jul 17]; Available from: http://www.opet.com.br/faculdade/revistapedagogia/pdf/n11/artigo4.pdf

23. Guedes MCR, Gomes CA. Consciência fonológica em período pré e pós-alfabetização. Cad Let da UFF - Dossiê Let e cognição [Internet]. 2010 [cited 2017 Jul 17];41:263-81. Available from: http://www. uff.br/cadernosdeletrasuff/41/cotidiano4.pdf 
24. Marchetti PT, Mezzomo CL, Cielo CA. Desempenho em consciência silábica e fonêmica em crianças com desenvolvimento de fala normal e desviante. Rev. CEFAC [Internet]. 2010 [cited 2017 Jul 17];12(1):12-20. Available from: http://www.scielo. $\mathrm{br} / \mathrm{pdf} / \mathrm{rcefac} / \mathrm{v} 12 \mathrm{n} 1 / 121-08 . p d f$

25. Scarpino SE, Lawrence FR, Davison MD, Hammer CS. Predicting bilingual spanish-english children's phonological awareness abilities from their preschool english and spanish oral language. $\mathrm{J}$ Res Read [Internet]. 2011 Feb 1 [cited 2017 Jul 17];34(1):77-93. Available from: http://www.ncbi. nlm.nih.gov/pubmed/23258945

26. Yeung SSS, Siegel LS, Chan CKK. Effects of a phonological awareness program on english reading and spelling among Hong Kong Chinese ESL children. Read Writ [Internet]. 2013 May [cited 2017 Jul 17];26(5):681-704. Available from: http:// www.ncbi.nlm.nih.gov/pubmed/23626405

27. Wertzner HF. Fonologia. In: Andrade CRF, Befi-Lopes DM, Fernandes FDM, Wertzner HF (orgs). ABFW Teste de linguagem infantil nas áreas de fonologia, vocabulário, fluência e pragmática. 2ed.rev. ampl. e atual. Barueri (SP): Pró-Fono, 2004. Cap. 1, Anexo 5. 1 CD Rom.

28. Seabra AG, Capovilla FC. Prova de consciência fonológica por produção oral. In: Seabra AG, Dias NM (orgs). Avaliação neuropsicológica cognitiva: Linguagem oral. Vol. 2. São Paulo: Memnon, 2012. p. 116-20.

29. Hambly H, Wren Y, McLeod S, Roulstone S. The influence of bilingualism on speech production: a systematic review. Int $\mathrm{J}$ Lang Commun Disord [Internet]. 2013 Jan [cited 2017 Jul 22];48(1):1-24. Available from: http://www.ncbi.nlm.nih.gov/ pubmed/23317381

30. Genaro KLX de. Desempenho fonológico de um grupo de crianças brasileiras que frequentam escola bilingue [Internet]. [Dissertação]: São Paulo (SP): Pontifícia Universidade Católica de São Paulo; 2013 [cited $2017 \mathrm{Jul}$ 28]. Available from: https:// sapientia.pucsp.br/bitstream/handle/11962/1/Karin Luzia Ximenes de Genaro.pdf

31. Cunha VLO, Capellini SA. Habilidades metalinguísticas no processo de alfabetização de escolares com transtorno de aprendizagem. Rev Psicopedag [Internet]. 2011 [cited 2017 Jul 28];28(85):85-96. Available from: http://pepsic. bvsalud.org/scielo.php?script =sci_arttext\& pid $=$ S0103-84862011000100009
32. Wertzner HF, Pagan L de O, Galea DE dos S, Papp ACCS. Características fonológicas de crianças com transtorno fonológico com e sem histórico de otite média. Rev da Soc Bras Fonoaudiol [Internet]. 2007 Mar [cited 2017 Jul 28];12(1):41-7. Available from: http://www.scielo.br/scielo.php?script $=$ sci arttext\&pid $=$ S1516-80342007000100009\&lng $=$ pt\& tlng $=\mathrm{pt}$

33. Mota HB, Berticelli A, Costa C da C, Wiethan FM, Melo RM. Occurrence of devoicing in phonological disorders: relationship with most affected phonemes, severity of the disorder and age. Rev da Soc Bras Fonoaudiol [Internet]. 2012 Dec [cited 2017 Jul 28];17(4):430-4. Available from: http://www.scielo.br/scielo.php?script $=$ sci arttext\&pid $=$ S1516-80342012000400011\&lng $=p t \&$ tlng $=p t$

34. Souza APR de, Mezzomo CL, Scotti LMC, Dias RF, Giacchini V. A influência da variável tonicidade na produção de sonoras. Distúrb Comun. 2013;25(1):57-63.

35. Loizou M, Stuart M. Phonological awareness in monolingual and bilingual english and greek five-year-olds. J Res Read. 2003;26(1):3-18.

36. Marinova-Todd SH, Zhao J, Bernhardt $M$. Phonological awareness skills in the two languages of mandarin-english bilingual children. Clin Linguist Phon [Internet]. 2010 [cited 2017 Jul 28];24(45):387-400. Available from: http://www.ncbi.nlm. nih.gov/pubmed/20345266

37. Mckay KL. Phonological awareness skill of segmenting in bilingual english/spanish speaking 4-and 5-year-old children [Internet]. Missoula. [Thesis Master of Science] Montana 5USA): University of Montana; 2012 [cited 2017 Jul 31]. Available from: http://scholarworks.umt.edu/etd

38. Nicoladis E, Charbonnier M, Popescu A. Second language/bilingualism at an early age with emphasis on its impact on early socio-cognitive and socio-emotional development. Encycopedia Early Child Dev [Internet]. 2016 [cited 2017 Jul 31];1(1):1-5. Available from: http://www.childencyclopedia.com/sites/default/files/textes-experts/ en/614/second-languagebilingualism-at-an-earlyage-with-emphasis-on-its-impact-on-early-sociocognitive-and-socio-emotional-development.pdf

39. Bruck M, Genesee F. Phonological awareness in young second language learners. J Child Lang. 1995;22(2):307-24. 
40. Labanca L, Alves CRL, Bragança LLC, Dorim DDR, Alvim CG, Lemos SMA. Language evaluation protocol for children aged 2 months to 23 months: analysis of sensitivity and specificity. CoDAS [Internet]. 2015 [cited 2017 Jul 26];27(2):119-27. Available from: http://www.scielo.br/pdf/codas/ v27n2/pt_2317-1782-codas-27-02-00119.pdf 